\title{
POVERTY IN RURAL AREAS: AN OUTLINE OF THE PROBLEM
}

\author{
Sławomir Kalinowski® \\ Institute of Rural and Agricultural Development, Polish Academy of Sciences, Poland
}

\begin{abstract}
This article is an attempt to determine the level of poverty in rural areas in Poland. The author reviewed the most important publications on poverty and the indicators that determine its scale. Relative, objective and subjective poverty lines were used to present the range of rural poverty against the background of total poverty. Analyses showed that the at-risk-of-poverty rate for rural areas in Poland amounted to $21.2 \%$. This means that almost every fifth rural resident is at risk of poverty, whereas every tenth resident is at risk of extreme poverty. The article also presents the rural areas in Poland which are at the highest risk of social exclusion. These areas were distinguished on the basis of the number of registered families receiving social benefits. Both Eurostat (EU-SILC) and Local Data Bank of the Statistics Poland (BDL GUS) were used.
\end{abstract}

Key words: poverty, rural areas, social exclusion

JEL codes: I31, I32, D31, D63

\section{INTRODUCTION}

Poverty and social exclusion have been the subjects of numerous empirical analyses [Rowentree 1901, Townsend 1979, Sen 1981, Atkinson 1987, Jarosz 2013, Tarkowska 2013, Galor et al. 2014, Golinowska 2018, Łuczak and Kalinowski 2020] due to the fact that a significant part of society is still unable to satisfy its basic needs. So far the authors of publications have recognised the following main groups of people to be threatened by poverty: the unemployed [Stiglitz 2009, Kryńska and Kwiatkowski 2010, ILO 2016, Quy 2016, Healy 2017], people with flexible forms of employment, known as the precariat [Standing 2014], the disabled [Emerson 2007, Kowalczyk et al. 2007, Golinowska and Sowa 2012], the poorly educated [Connelly et al. 2014, Serneels and Dercon 2014], elderly people [Kubicki 2013, Kałuża and Szukalski 2014], children [Warzywoda-Kruszyńska 2012,
OECD 2015, UNICEF 2016], women [Lister 2007, European Commission 2017] and the rural population [Kalinowski and Łuczka-Bakuła 2007, Binder 2014, Kalinowski 2015].

As poverty itself is a multidimensional phenomenon, it is extremely difficult to analyse. Depending on the assumed concept of the poverty line, different people may be below the threshold separating the poor from those who are not poor. However, the core of the groups usually remains the same. It is noteworthy that there is no single understanding of poverty. It varies depending on the context, place, or one's ability to cope with it.

The rural population is unquestionably one of the major groups at risk of poverty. All analyses indicate that this group satisfies its needs to a lesser extent than city dwellers, and rural inhabitants usually have lower expectations [Kalinowski 2016]. This group is particularly important for research on poverty, be- 
cause about $40 \%$ of the Polish population lives in rural areas, i.e. about 15.3 million inhabitants. However, it is important to stress the diversity of rural areas themselves, which face different problems, depending on their functional type [Stanny et al. 2018]. The level of poverty and material deprivation is both demographically and spatially diversified. Therefore, the aim of the analysis was to indicate the extent of rural poverty and its diversity.

\section{DEFINITION PROBLEMS AND METHODS}

Poverty is a social phenomenon which consists in a lack of adequate material resources to cover a certain level of expenditure on goods and services. As a result, people become marginalised and unable to use goods and services according to their needs. Poverty refers to the people who limit their expenses below the minimum accepted by the inhabitants of a particular country. In a narrower sense, it also refers to specific territories in a country (e.g. peripheral areas located far away from large urban agglomerations). The problem of poverty does not boil down only to a lack of cash or to a level of individual consumption below the assumed threshold. It is also a matter of consumer convention - objectively determinable deprivation of needs - which hinders one's participation in social life. Nevertheless, although the income dimension is not optimal, it is commonly used, and it is treated as the second-best solution. Clarity is an important advantage of poverty lines determined by means of specific income, because it enables easy separation of the poor subpopulation from the rest of society. However, it is important to stress the fact that having income is not necessarily synonymous with the ability to satisfy one's needs. Some studies point to the uneven distribution of income within a household, while others indicate the inconsistency of the objective and subjective dimensions of a life situation - the satisfaction paradox or dissatisfaction dissonance [Kalinowski 2016].

There are two approaches to defining poverty: broad and narrow. The first is characteristic of sociology, because it comprises research on this phenomenon not only in a sense of existence, but also on the basis of multidimensional and descriptive statistics, which enables assessment of psychological, social and cultural aspects. The other definition is typical of economic research, which usually has a practical purpose, namely to identify the range of poverty and to determine the scale of measures that are necessary to eliminate it. In this case, poverty is defined by means of economic concepts, whereas the criteria and measures used in research are measurable and unambiguous [Panek et al. 1999]. According to Golinowska [1997], there is no universal concept of poverty. It has specific content, which is grounded in a broader economic and social context.

There are two approaches to identification of the poverty line in analyses of the standard of living: economic and multidimensional. The first approach is based on income, whereas the other one also takes non-economic factors into account. Determining the poverty line by means of income (in an objective approach) results from its symbolic nature. Although income is a means rather than an end, it can be used for gradation of the possibility to satisfy one's needs. However, it is noteworthy that high income is not necessarily reflected by high consumption, and vice versa. Although neither possession nor the lack of resources can be fully equated with the standard of living, numerous studies have confirmed the convergence of both categories. The objective approach includes absolute measures (social minimum, subsistence minimum, legal poverty) and the parametric approach (income median, income quantiles). Apart from objective lines, subjective lines are also significant, because they make it possible to determine respondents' attitudes to their own financial situation.

For further analysis, it is necessary to clarify what the definition of poverty is. Although there are many definitions of poverty, in the European Union countries, a standard methodology was adopted by Eurostat (Statistical Office of the European Union). People living in households whose disposable income is lower than the poverty line determined by $60 \%$ of the median income in a given country are considered to be at risk of poverty. A parametric approach to measuring poverty has been adopted, which is linked to the standard of living in individual countries. It should be 
noted that poverty defines a group of people with the relatively most difficult situation in a given country. Thus, poverty in individual countries is not relevant to the level of income in other countries. It can be seen, therefore, that a poor inhabitant of the wealthiest countries can also be treated as a wealthy person in the poorest countries.

It should be noted that the article uses two concepts related to poverty. First is the risk of poverty or social exclusion, the second is the at-risk-of-poverty threshold. At risk of poverty or social exclusion (AROPE) corresponds to the sum of persons who are either at risk of poverty or severely materially deprived or living in a household with a very low work intensity. Persons are only counted once even if they are present in several sub-indicators. The AROPE rate, the share of the total population at risk of poverty or social exclusion, is the headline indicator to monitor the EU 2020 Strategy poverty target. The at-risk-of-poverty rate is the share of people with an equivalised disposable income (after social transfer) below the at-risk-of-poverty threshold, which is set at $60 \%$ of the national median equivalised disposable income after social transfers [Regulation EC 1177/2003].

It is also worth noting that material deprivation refers to a state of economic strain and durables, defined as the enforced (rather than voluntary) inability to pay unexpected expenses, afford a one-week annual holiday away from home, a meal involving meat, chicken or fish every second day, the adequate heating of a dwelling, durable goods like a washing machine, colour television, telephone or car, or being confronted with payment arrears (mortgage or rent, utility bills, hire purchase instalments or other loan payments). The severe material deprivation rate is an indicator in the EU-SILC that expresses as the enforced inability to pay for at least four of the above-mentioned items. The indicator distinguishes between individuals who cannot afford a certain good or service and those who do not have this good or service for another reason, e.g. because they do not want or do not need it.
The second of the sub-category of social exclusion is persons living in households with very low work intensity. This indicator is defined as the number of persons living in a household where the members of working age worked less than $20 \%$ of their total potential during the previous 12 months. Additionally, the work intensity of a household is the ratio of the total number of months that all working-age household members have worked during the income reference year and the total number of months the same household members theoretically could have worked in the same period ${ }^{1}$.

The empirical data in the article come from the EU-SILC (European Union Statistics on Income and Living Conditions), which are contained in the Eurostat materials ${ }^{2}$. They are a reference point for comparing statistics on income distribution and social integration in the European Union. They have been used since 2003 (in the beginning in Austria, Belgium, Denmark, Greece, Ireland and Luxembourg, and since 2004 in all the EU member states) to monitor the social policy by means of the Open Method of Coordination (OMC). These surveys are a universal tool focused on income, especially personal income, poverty, social exclusion and living conditions. The EU-SILC surveyed all household members over the age of 16 in the individual countries. An employee's income was assumed to be the total remuneration paid to them in money or in kind in return for work done within a specific period of time.

At-risk-of-poverty thresholds (ARPT) broken down by each combination of dimensions ( $k$ ) (ARPTat_k) is calculated as the percentage of people (or thousands of people) in each $k$ who are at-risk-of-poverty (calculated for different cut-off points) over the total population in that $k$. The weight variable used is the Adjusted Cross Sectional Weight (RB050a).

$$
A R P T_{a t_{k}}=\frac{\sum_{i=j_{a k k}} R B 050 a_{i}}{\sum_{i_{a l k}} R B 050 a_{i}} 100
$$

\footnotetext{
${ }^{1}$ Eurostat. Statistics Explained, https://ec.europa.eu/eurostat/statistics-explained/index.php/Glossary:Persons_living_in_ households_with_low_work_intensity

${ }^{2}$ Eurostat. Income and living conditions (ilc), https://ec.europa.eu/eurostat/web/income-and-living-conditions/data/database
} 
where $j$ denotes the population or subset of the population, who is at risk of poverty. At-risk-of-poverty thresholds $(A R P T X X)$ can be any of the following: ARPT40, ARPT50, ARPT60, ARPT70, however, only the median threshold of $60 \%$ of the equivalent income is used in the research conducted in this article.

\section{RISK OF POVERTY OR SOCIAL EXCLUSION}

Relative (parametric) measures are commonly used in the EU to separate the poor from those who are not poor. One of these measures is the at-risk-of-poverty rate, which refers to the share of people whose income is lower than $60 \%$ of the median equivalised income (having included social transfers). According to this approach, the poor are those whose income is lower than the income of other members of society. This measure determines the degree of income inequality rather than the extent of poverty. It is not difficult to notice that non-poor people may be below this line and vice versa. In research on poverty in the EU, the people who are experiencing severe material deprivation or living in a household with low labour intensity are also included in the group at risk of poverty. On this basis, it is possible to say that in $2018,21.9 \%$ of all inhabitants in the EU and $23.7 \%$ of rural inhabitants were at risk of poverty or social exclusion (Fig. 1). Detailed analysis showed that the situation of the rural population in Bulgaria, Romania, Lithuania, Greece and Latvia was the worst, whereas it was relatively the best in the Czech Republic, the Netherlands, France and Austria. In Poland the at-risk-of-poverty ratio was $25.3 \%$, which was close to the EU average.

However, it is worth paying attention to changes in the extent of relative deprivation when only poverty is taken into account and non-income factors are eliminated. Then the percentage of people below the poverty line in the total population drops by 4.8 p.p., whereas the percentage in the rural population drops by 4.3 p.p. When non-income factors were eliminated, the rural inhabitants in Romania, Bulgaria, Lithuania and Latvia were still at the highest risk of poverty, whereas the rural inhabitants in the Czech Republic, the Netherlands and France were at the lowest risk (Table 1).

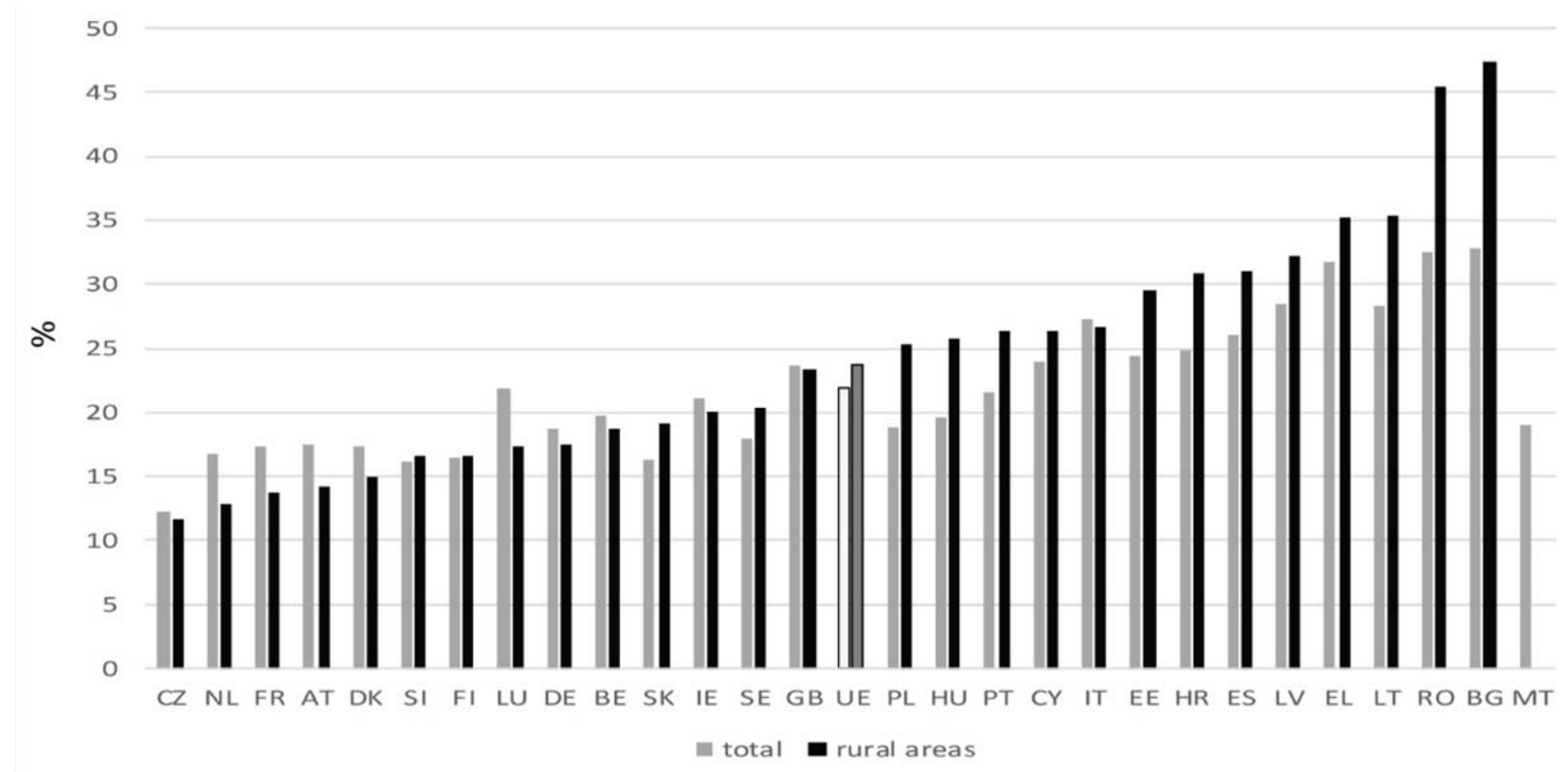

Fig. 1. The at-risk-of-poverty or social exclusion ratio in individual EU member states and in rural areas in 2018 Source: Eurostat ilc_peps01, ilc_peps13. 
Table 1. The at-risk-of-poverty rate in 2018 (total and rural areas)

\begin{tabular}{|c|c|c|}
\hline Specification & Total & Rural areas \\
\hline European Union & 17.1 & 19.4 \\
\hline Belgium & 16.4 & 15.5 \\
\hline Bulgaria & 22.0 & 36.8 \\
\hline Czech Republic & 9.6 & 9.2 \\
\hline Denmark & 12.7 & 11.3 \\
\hline Germany & 16.0 & 15.8 \\
\hline Estonia & 21.9 & 26.5 \\
\hline Ireland & 14.9 & 15.6 \\
\hline Greece & 18.5 & 22.5 \\
\hline Spain & 21.5 & 26.1 \\
\hline France & 13.4 & 10.6 \\
\hline Croatia & 19.3 & 25.9 \\
\hline Italy & 20.3 & 20.4 \\
\hline Cyprus & 15.4 & 18.1 \\
\hline$\overline{\text { Latvia }}$ & 23.3 & 27.3 \\
\hline Lithuania & 22.9 & 30.1 \\
\hline Luxembourg & 18.3 & 13.8 \\
\hline Hungary & 12.8 & 16.6 \\
\hline Malta & 16.8 & : \\
\hline Netherlands & 13.3 & 10.4 \\
\hline Austria & 14.3 & 11.6 \\
\hline Poland & 14.8 & 21.2 \\
\hline Portugal & 17.3 & 22.5 \\
\hline Romania & 23.5 & 39.0 \\
\hline Slovenia & 13.3 & 13.4 \\
\hline Slovakia & 12.2 & 14.8 \\
\hline Finland & 12.0 & 12.8 \\
\hline Sweden & 16.4 & 19.3 \\
\hline United Kingdom & 18.9 & 20.2 \\
\hline
\end{tabular}

Source: Eurostat ilc_li02.

\section{RISK OF RURAL POVERTY IN POLAND}

It is worth analysing changes in the risk of relative poverty in Poland after its accession to the EU. While in 2005 almost every fifth Pole was at risk of poverty, in 2018 this percentage dropped by more than a quarter - from 20.5 to $14.8 \%$. Rural inhabitants can also be satisfied with Poland's accession to the EU, because the poverty rate dropped from 27.2 to $21.2 \%$ (Fig. 2). At that time the poverty threshold per capita increased from PLN 6,880 to 16,790 (the threshold of $60 \%$ of the median equivalised income). In households with two adults and two children it increased from PLN 14,448 to 35,260 . During the period under analysis the lowest relative poverty rate was in 2017 , i.e. $20.1 \%$, whereas a year later it increased by more than one percentage point (Fig. 2). This fact is intriguing because 2018 was unprecedented in the history of Poland in terms of social transfers (including the Family 500 Plus programme).

As mentioned before, relative poverty only partly shows people's actual deprivation of the ability to satisfy their needs. It is rather a determinant of economic inequality. In order to identify the people who are deprived of their needs the most it is important to indicate extremely poor people and those who are entitled to social benefits (legal poverty). Extreme poverty is particularly dangerous, because it indicates the number of people who are deprived of their needs to such an extent that it poses a threat to their lives or psychophysical state. The minimum subsistence is the line that enables identification of the number of people whose standard of living is below this level. When determining minimum subsistence, it is necessary to specify the content of the basket of goods that are indispensable for survival and cannot be purchased at a later date. In 2018 the minimum subsistence level for a household with one person employed was PLN 591.14, whereas for a household with two adults and two children the minimum subsistence level was PLN 503.57 per capita [Kurowski 2019].

The analysis of extreme poverty in Poland showed that in comparison with 2010, its level did not change much, although this change was noticeable over the years. It is noteworthy that the poverty rate was 


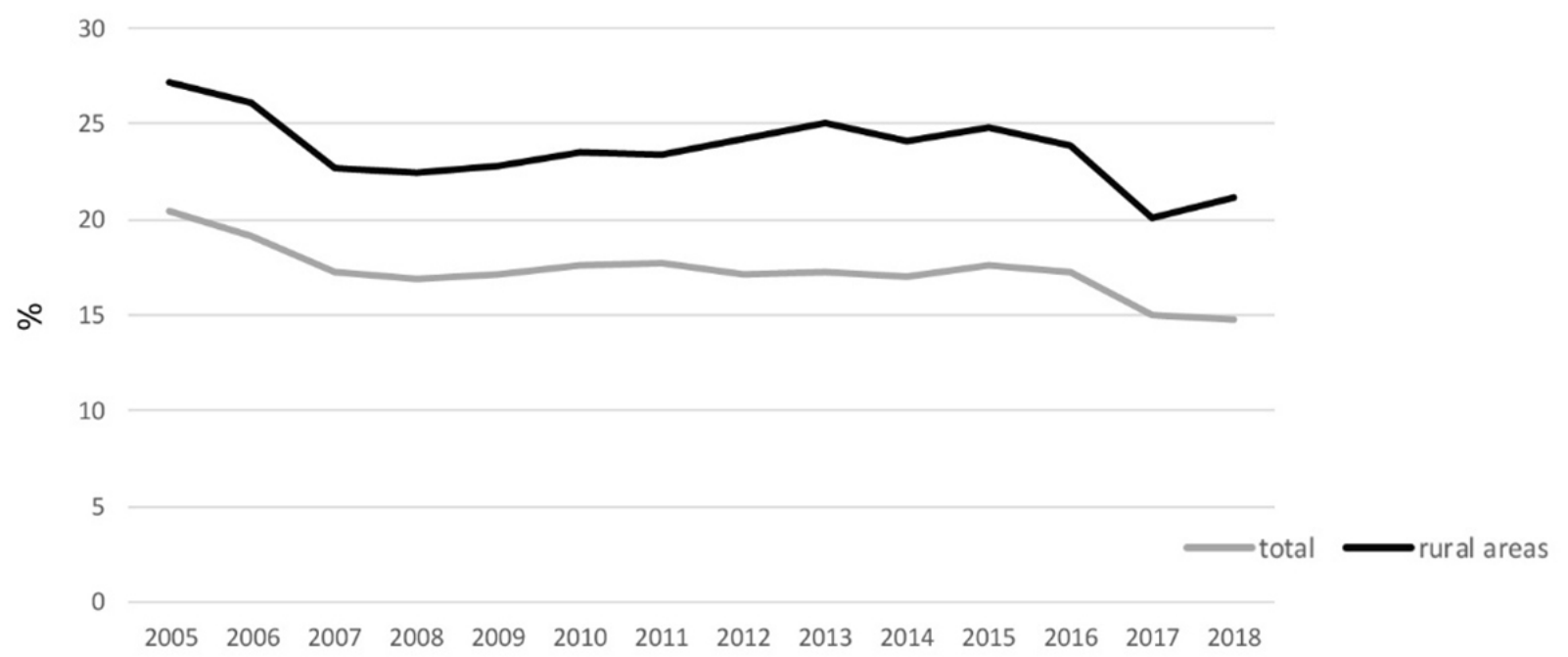

Fig. 2. At-risk-of-poverty rate in Poland in 2005-2018 (total and rural areas)

Source: Eurostat ilc_li02.

increasing gradually until 2014, when it reached its highest level (11.8\%). When the Family 500 Plus programme was introduced, the poverty rate was decreasing until 2017. However, in comparison with 2017, in 2018 extreme poverty in rural areas increased again and amounted to $9.4 \%$. The range of poverty determined by means of a legal line was much greater due to a higher threshold that was set for applicants for social benefits [Ustawa $\mathrm{z}$ dnia 12 marca $2004 \mathrm{r}$. o pomocy społecznej]. In 2018 it was PLN 701 for a household with one person and PLN 2,112 for a household with four people, i.e. PLN 528 per capita [GUS 2019]. In comparison with 2010 the percentage of people at risk of legal poverty increased by 5.7 p.p. (Fig. 3).

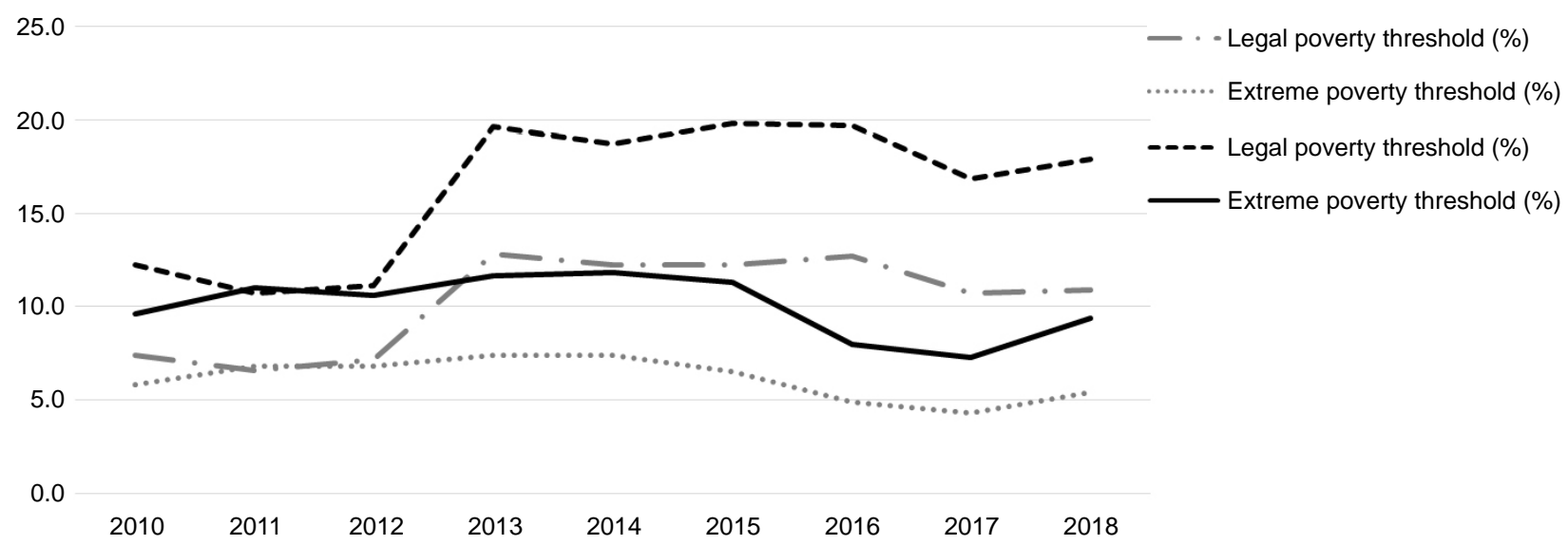

Fig. 3. Total extreme and legal poverty thresholds and extreme and legal poverty thresholds in rural areas in Poland between 2010 and 2018

Source: Local Data Bank of Statistics Poland. 
Apart from income, people's behaviour is influenced by many other economic and non-economic factors with objective and subjective nature. It can be assumed that even wealthy rural inhabitants will not practise more sophisticated patterns of spending their free time due to infrastructural deficiencies rather than low standard of living. Also, participation in high culture is usually not their aspiration. Due to the lack of reference standards there is no need to follow them. On the other hand, the interconnection of services to infrastructure deprives a large group of people living in rural areas of the chance to use them. It also significantly differentiates the ability to consume services. These factors result in a sense of inability to satisfy one's needs and translate into the level of subjective poverty. They are considered the most democratic methods of defining poverty by setting individual thresholds of satisfying one's needs. The Statistics Poland (Główny Urząd Statystyczny - GUS) defines subjective poverty by individual assessment of one's own situation and indicating whether it is very good, good, average, rather bad or very bad. This is the basis for separating the people who have the sense they can satisfy their needs from those who have difficulties achieving it. The analysis of data shows that rural inhabitants rate their own situation as very good or rather good less often than other inhabitants (Table 2).
From the point of view of social security tasks, it is important to differentiate the poverty level spatially. Such analysis enables differentiation of the level of assistance provided to individual areas so that it can be better targeted. The percentage of people in families covered by the social security system in the total population of a commune is the indicator that enables determination of the range of poverty. Although this indicator is not synonymous with poverty, it can be assumed to be adequate for spatial considerations. It can be assumed that this percentage coincides with poverty determined by means of the legal minimum. Figure 4 shows the areas whose inhabitants are at the highest risk of deprivation of their needs. Analyses showed that the inhabitants of rural areas in northern and eastern Poland benefited from social security the most. It is also noteworthy that the further away people live from large and significant urban agglomerations, the higher the significant risk of being below the legal poverty threshold is. Thus, it is possible to assume that the inhabitants of peripheral areas of voivodeships are at higher risk of the inability to satisfy their needs than those living close to cities. The research conducted by Chrzanowska and Pomianek [2018] also showed that living conditions in peripheral areas were worse. This statement is obvious in view of people's migration opportunities and sustainability of the labour market.

Table 2. Inhabitants' subjective rating of their situation in 2018

\begin{tabular}{lcc}
\hline \multirow{2}{*}{ Specification } & Total & Rural areas \\
\cline { 2 - 3 } & & $\%$ \\
\hline Very good & 20.9 & 16.6 \\
\hline Rather good & 23.1 & 22.7 \\
\hline Average & 47.9 & 52.1 \\
\hline Rather bad & 6.2 & 6.9 \\
\hline Bad & 1.9 & 1.8 \\
\hline
\end{tabular}

Source: Local Data Bank of Statistics Poland. 


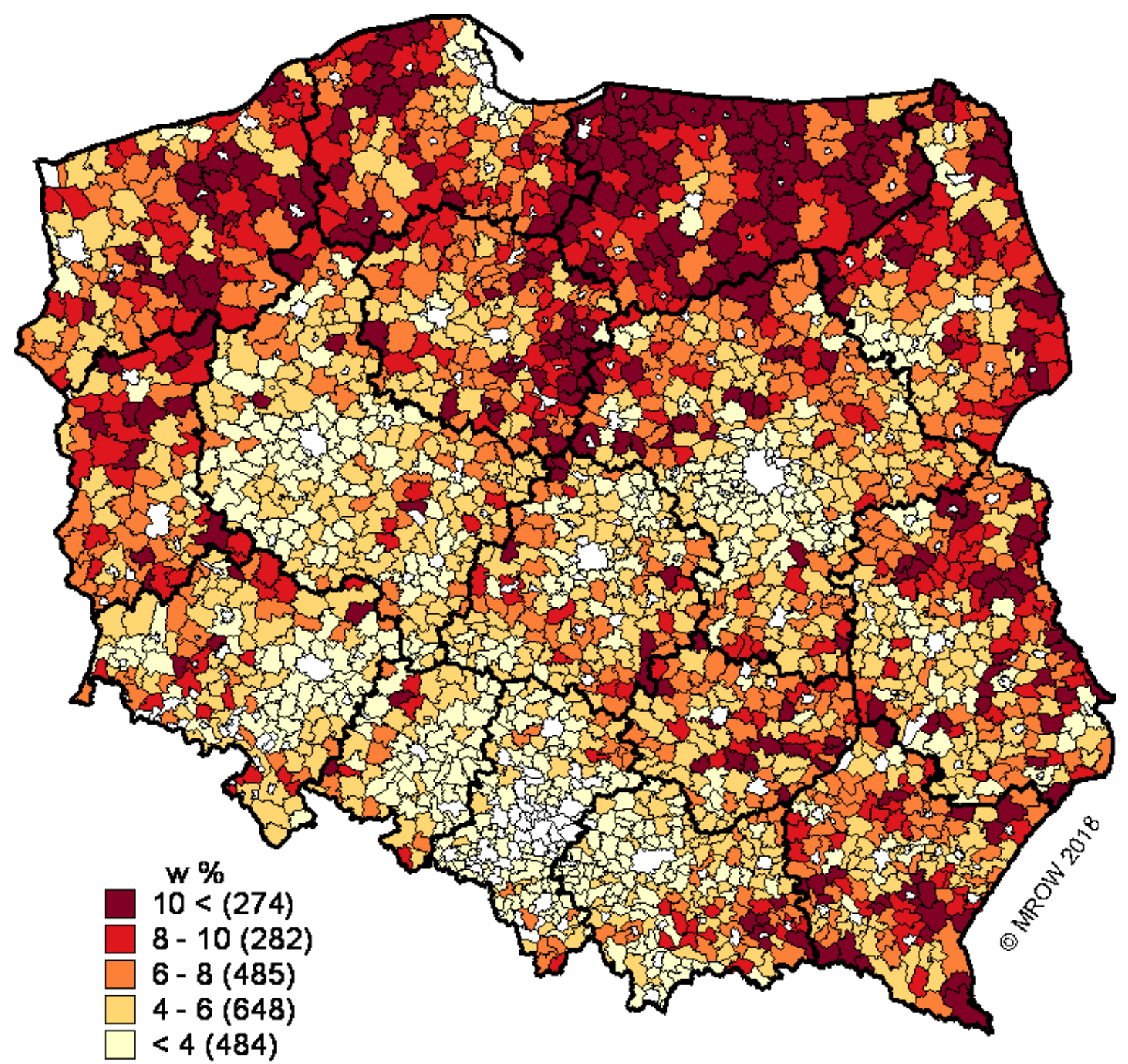

Fig. 4. The percentage of people in families covered by the social security system in the total population of communes Source: Stanny et al. [2019].

\section{CONCLUSIONS}

Poverty in rural areas is an extremely broad issue. Due to such a broad approach to the problem and a high variety of factors affecting it, it is impossible to discuss it fully in an article. As there are so many approaches, only a few of them can be selected for analysis. It is obvious that this article cannot be treated as a review of the entire issue of rural poverty, but it can contribute to further analysis. The author did not present solutions preventing poverty in the article, because that was not its goal.

The data presented in the article showed that:

- The scale of poverty in rural areas is larger than the scale of total poverty, regardless of the poverty line assumed (objective, relative, subjective). Although the article does not provide information about the scale of poverty in urban areas, it is possible to guess from the indicators for the total area of Poland that it is significantly lower. 
- The at-risk-of-poverty rate in the countries that joined the EU before 2004 is much lower than in those that joined the community after that date. This observation also applies to rural areas.

- The inhabitants of peripheral areas are at higher risk of legal poverty than the people who live near major cities in provinces or close to larger towns in counties.

- Rural inhabitants in northern and eastern Poland are at higher risk of poverty than rural dwellers in other regions of Poland.

\section{REFERENCES}

Atkinson, A.B. (1987). On the measurement of poverty. Econometrica, 55 (4), 749-764.

Binder, P. (2014). Młodzi a bieda. Strategie radzenia sobie w doświadczeniu młodego pokolenia wsi pokołchozowych i popegeerowskich. Instytut Filozofii i Socjologii PAN, Warszawa.

Chrzanowska, M., Pomianek, I. (2018). Multidimensional Statistical Analysis of Changes in Living Conditions in Mazowieckie Voivodship Compared to Other Polish Voivodeships in the Period 2005-2016. Zeszyty Naukowe Wyższej Szkoły Ekonomiczno-Społecznej w Ostrołęce, 31, 227-234.

Connelly, R., Sullivan, A., Jerrim, J. (2014). Primary and secondary education and poverty review. Centre for Longitudinal Studies Institute of Education, London.

Emerson, E. (2007). Poverty and people with intellectual disabilities. Mental Retardation and Developmental Disabilities Research Reviews, 13 (2), 107-113.

European Commission (2017). 2017 report on equality between women and men in the EU. Directorate-General for Justice and Consumers, Brussels, https://doi. org/10.2838/52591

Galor, Z., Goryńska-Bittner, B., Kalinowski, S. (Eds.) (2014). Życie na skraju - marginesy społeczne wielkiego miasta. Wydawnictwo Societas Pars Mundi, Bielefeld.

Główny Urząd Statystyczny - GUS (2019). Zasięg ubóstwa ekonomicznego w Polsce w 2018 r. Informacje Sygnalne 28.06.2019.

Golinowska, S. (1997). Badania nad ubóstwem. Założenia i metoda. [In:] S. Golinowska (Ed.), Polska bieda II. Kryteria. Ocena. Przeciwdziałanie. Instytut Pracy i Spraw Socjalnych, Warszawa.

Golinowska, S. (2018). O polskiej biedzie w latach 1990-2015. Definicje, miary i wyniki. Wydawnictwo Naukowe Scholar, Warszawa.
Golinowska, S. (Ed.) (1997). Polska bieda II. Kryteria, ocena, przeciwdziałanie. Instytut Pracy i Spraw Socjalnych, Warszawa.

Golinowska, S., Sowa, A. (2012). Determinanty niepełnosprawności. [In:] S. Golinowska (Ed.), Instytucjonalne, zdrowotne i społeczne determinanty niepełnosprawności. Instytut Pracy i Spraw Socjalnych, Warszawa, 68-99.

Healy, S. (2017). Strategies to combat poverty and generate decent employment in the European Union. Presentation at UN Expert Group. New York.

International Labour Organization - ILO (2016). World Employment and Social Outlook 2016: Transforming jobs to end poverty. International Labour Office, Geneva.

Jarosz, M. (Ed.) (2013). Polskie bieguny. Instytut Studiów Politycznych PAN, Warszawa.

Kalinowski, S. (2015). Poziom życia ludności wiejskiej o niepewnych dochodach. Wydawnictwo Naukowe PWN, Warszawa.

Kalinowski, S. (2016). „Pieniądze szczęścia nie dają... być może" - oblicza niespójności opinii ludności wiejskiej o niepewnych dochodach. Polityka Społeczna, 2 (503), 16-20.

Kalinowski, S., Łuczka-Bakuła, W. (2007). Ubóstwo ludności wiejskiej województwa wielkopolskiego. Wydawnictwo Akademii Rolniczej w Poznaniu, Poznań.

Kałuża, D.P., Szukalski, P. (Eds.) (2014). Jakość życia seniorów w XXI wieku z perspektywy polityki społecznej. Wydawnictwo Biblioteka, Łódź.

Kowalczyk, O., Gilga, K., Jurek, Ł. (2007). Aktywność społeczna i poziom życia osób niepełnosprawnych na Dolnym Śląsku. Indygo, Wrocław.

Kryńska, E., Kwiatkowski, E. (2010). Polityka państwa wobec rynku pracy: idee ekonomiczne i rzeczywistość. Polityka Społeczna, 5-6, 1-7.

Kubicki, P. (2013). Ubóstwo i wykluczenie osób starszych. European Anti-Poverty Network, Warszawa.

Kurowski, P. (2019). Informacja o poziomie minimum egzystencji w 2018 r. Instytut Pracy i Spraw Socjalnych, Warszawa.

Lister, R. (2007). Bieda. Wydawnictwo Sic!, Warszawa.

Łuczak, A., Kalinowski, S. (2020). Assessing the level of the material deprivation of European Union countries. PLOS ONE, 15 (9), e0238376, https://doi.org/10.1371/ journal.pone. 0238376

Organisation for Economic Cooperation and Development - OECD (2015). OECD Skills Outlook 2015: Youth, Skills and Employability. OECD Publishing, Paris.

Panek, T., Podgórski, J., Szulc, A. (1999). Ubóstwo, teoria i praktyka pomiaru. Monografie i Opracowania 453. Oficyna Wydawnicza SGH, Warszawa. 
Quy, N.H. (2016). Relationship between Economic Growth, Unemployment and Poverty: Analysis at Provincial Level in Vietnam. International Journal of Economics and Finance, 8 (12), 113-119.

Regulation EC No $1177 / 2003$ of the European Parliament and of the Council of 16 June 2003 concerning Community statistics on income and living conditions (EU-SILC) (Text with EEA relevance). OJ L 165 of 03.07.2003.

Rowntree, B.S. (1901). Poverty: A study of town life. Macmillan, London.

Sen, A. (1981). Poverty and famines: An essay on entitlement and deprivation. Clarendon Press, Oxford.

Serneels, P., Dercon, S. (2014). Aspirations, Poverty and Education Evidence from India. Oxford Department of International Development, Oxford.

Standing, G. (2014). Prekariat - nowa niebezpieczna klasa. Wydawnictwo Naukowe PWN, Warszawa.

Stanny, M., Rosner, A., Komorowski, Ł. (2018). Monitoring rozwoju obszarów wiejskich. Etap III. Struktury społeczno-gospodarcze, ich przestrzenne zróżnico- wanie i dynamika. Europejski Fundusz Rozwoju Wsi Polskiej, Instytut Rozwoju Wsi i Rolnictwa PAN, Warszawa.

Stiglitz, J. (2009). The Global crisis, social protection and jobs. International Labour Review, 148 (1-2), 1-13.

Tarkowska, E. (Ed.) (2013). Dyskursy ubóstwa i wykluczenia społecznego. Instytut Filozofii i Socjologii PAN, Warszawa.

Townsend, P. (1979). Poverty in the United Kingdom. A Survey of Household Resources and Standards of Living. Penguin Books and Allen Lane, London.

United Nations Children's Fund - UNICEF (2016). Fairness for Children. A league table of inequality in child well-being in rich countries. Report Card 13.

Ustawa z dnia 12 marca 2004 r. o pomocy społecznej. Dz.U. $2004 \mathrm{nr}$ 64, poz. 593 [Social Security Act of 12 March 2004. Journal of Laws 2004 No 64, item 593].

Warzywoda-Kruszyńska, W. (Ed.) (2012). Bieda dzieci. Zaniedbanie. Wykluczenie społeczne. Wydawnictwo Uniwersytetu Łódzkiego, Łódź.

\section{UBÓSTWO NA WSI. ZARYS PROBLEMU}

\section{STRESZCZENIE}

W artykule podjęto próbę określenia poziomu ubóstwa w Polsce. Przedstawiono przegląd najważniejszej literatury dotyczącej ubóstwa, a także wskaźniki, które stosowane są do określenia jego wielkości. Za pomocą ubóstwa relatywnego, obiektywnego i subiektywnego przedstawiono zasięg ubóstwa wiejskiego na tle ubóstwa ogółem. Na podstawie analiz zauważono, że wskaźnik zagrożenia ubóstwem na obszarach wiejskich w Polsce wynosi 21,2\%, niemal co piąty mieszkaniec wsi zagrożony jest ubóstwem ustawowym, a co dziesiąty ubóstwem skrajnym. W artykule przedstawiono również obszary wiejskie w Polsce w największym stopniu zagrożone ekskluzją społeczną. Obszary te wyróżniono na podstawie zarejestrowanej liczby rodzin pobierających zasiłki z pomocy społecznej.

Słowa kluczowe: ubóstwo, obszary wiejskie, wykluczenie społeczne 